\title{
Women's Participation in Village Developent Planning: Case of Indonesia
}

\author{
Dian Andryanto ${ }^{a *}$ \\ ${ }^{a}$ Local Government of Pemalang, Pemalang - Central Java
}

\section{ARTICLE INFORMATION}

\section{Article history:}

Data submission : 29 August 2020

$1^{\text {st }}$ revision: 10 October 2021

Accepted: 10 November 2021

Available online: 10 December 2021

Keywords: village law, women participation, village planning, participatory governance

\begin{abstract}
The introduction of participatory processes concerning village development planning by Law 6/2014 on Village open up the opportunity for village communities to shape village development priorities. It is expected that village community involvement over village planning will make village government more accoutable downwardly and village development be responsive to villagers problems and needs. Using literature review, the present paper inspects closely a body of literature to ensure that women and other historically marginalized groups have chance to participate meaningfully in these processes. The reviewed literature suggest a divergence between what scholars believe about advantages of participatory processes and limited impact of such. Similarly, within this nascent stage of village law implementation participatory spaces in determining village development priorities are still dominated by village elites and men, and village development is heavily focus on infrastructure development. However, the presence and empowered women's organizations or groups which exists in villages might influential to drivw village development priorities that are responsive for women. What we learned from these body of literature is that meaningful participation by women and other historically disadvantaged groups can only be achieved through continious intervention and facilitation either by dedicated and reform-minded public officials and other critical actors. Furthermore women should involve in participatory village development planning as a collective, rather than as individuals.
\end{abstract}

2021 FIA UB. All rights reserved.

\section{Introduction}

In 2014 Indonesian government signed Law Number $6 / 2014$ concerning Villages aimed to enhance village decentralization which had been started since 2001 (Antlov et al., 2016). The law grants villages with rights and resources in governing villages affairs. Furthermore, it also facilitates village communities as the subject of development with the rights to collectively determine village development priorities with village government through the introduction of participatory processes that consist of sub-village meeting and village meeting. Through these participatory spaces, it is expected that village development will be inclusive be responsive to village community's needs. Antlov et al. (2016) asserts the importance of the presence of empowered village citizens to demand development priorities that are responsive to their problems to make the implementation of village law more effective in achieving its objectives.

Conceptually this new legal framework of Indonesian village governance resembles Wampler and McNulty (2011) and Fischer (2012) concept of 'participatory governance'. The main feature of participatory governance is the presence of a formal participatory decision-making forum in which citizens together with state officials discuss, deliberate, and reach agreements on the allocation of public resources (Wampler \& McNulty, 2011). Similarly, Fischer (2012) underlies that participatory governance is identical with 'a new space for decision-making' that allow citizens to voice their aspirations concerning local development priorities.

Within this nascent stage of the implementation of village law it is important to inspect closely a body of literature that capture experiences of participatory 
governance experimentation in order to gain insight in assisting villager participation in determining development priority. Special attention will be given to women's participation, since they were considered historically marginalized group in the context of participatory governance (Cornwall, 2003; McNulty, 2018). On the other hand, there is a growing body of literature on the importance of women's participation in local decision-making processes. For instance, Hicks (2011) and Masanyiwa et al. (2014) noted that women's participation in participatory decision-making is seen as a mean to strengthen gender-sensitivity to local conditions and priorities, thus enabling greater influence of women over planning and service delivery.

The present paper is organized as follows. The next section provides brief description about method used in this study. The third section provide literature review from body of literature concerning the current village participatory development planning, participatory governance, and how Indonesian villages exercise participatory village development sourced from published reports. Finally, the paper concludes with policy implications and suggestions based on results and discussion.

\section{Discussion}

\subsection{Changes of Village Development Planning}

In the Indonesian unitary system, the village is the bottommost in the five tiers of government administration after sub-district, regency or city, province, and national government. Over the past 40 years there have been significant changes on village governance legal frameworks which in turns substantially shaping the approach to developing villages (Antlov et al. 2016). During centralistic New Order under Suharto presidency almost development programs that took place in villages was dictated and devised by central government (Sutiyo \& Maharjan, 2017). At village level, Usui and Alisjahbana (2005) and Widianingsih and Morelli (2007) briefly described that during this time village development planning was carried out by village head supported by a government organization known as the Community Strengthening Institute (Lembaga Ketahanan Masyarakat Desa, or LKMD).

After central government issued Law 22/99 concerning decentralization into sub-national government, Usui and Alisjahbana (2005) noted that the nature of sub-national development planning at this stage is a combination of top down and bottom-up approach. At village level Antlov et al. (2003) found that village development planning was jointly decided by village government and BPD without involving villagers at large. However, Usui and Alisjahbana (2005) and Widianingsih and Morell (2007) reported that ordinary villagers have been involved in participatory planning process (Musrenbang) in the drafting of local (district) government development plan. Nevertheless, both studies also claim that it just a symbolic and formality process.

In 2007, the central government introduce village mid-term development planning (RPJMDes) through the enactment of Ministry of Home Affair (MOHA) regulation (Permendagri) 66/2007 and Technical Instructions 414.2/1408/PMD on March 31, 2010 (Antlov \& Eko, 2012). These regulations state that village development should be based on RPJMDes, which will be effective for six years' period. This planning document should be drafted by a team that consists of eleven members who represent the village government, community, and other village institutions (Antlov \& Eko, 2012).

Meanwhile since 2007 until 2014 communities within villages also began to experience participation in National Program of Community Empowerment (PNPM). This was Indonesian government program aimed to reduce poverty by providing communities of nearly 70.000 Indonesian villages with block grant and participatory processes in determining local-scale development priority. Furthermore, local communities were expected to get direct benefit from program implementation through their participation in project implementation. To support this program government also employed facilitators to facilitate this participatory process and to assist involved community throughout the project cycle.

The current village development planning under the Village Law framework is regulated through Ministerial Regulation of the Ministry of Home Affairs (MOHA) $114 / 2014$. It stipulates that the formulation of village development plan should involve villagers. To facilitate villagers' involvement, the regulation requires the drafting team, which is formed by the village head, to convene a series of consultative meetings. These meetings are known as hamlet or sub-village meetings. It serves as a channel for villagers to demand village development programs that are responsive to their problems. In addition, this ministerial regulation also allows village communities or groups to organize designated group meetings, such as farmers or women's groups, for similar purposes.

Furthermore, the regulation states that decisionmaking over village development priorities should be made through village meetings. Such meetings are supposed to be facilitated by the BPD, between representatives of each group or organization that exists within a given village and the village government, who 
are expectedly to discuss and collectively approve on village development priorities that can be implemented effectively for six years. In sum, participatory processes to formulate village development planning consist of consultative meetings, which in general are held at the sub-village level (hamlet or neighborhood) and village meetings. Previous studies, among others TNP2K (2015), ADB (2016) asserted that the participatory processes in determining village development priority is adopted from National Program of Community Empowerment (PNPM). ADB (2016) noted that PNPM was the largest community-driven development program in the world which had been implemented during 2007 2014 in nearly 70.000 Indonesian villages. PNPM provides block grants, participatory processes in determining development priority at grassroots level, and facilitators to assist communities throughout the project cycle.

\subsection{Participatory Governance}

Fung and Wright (2001) describe participatory governance as a form of experiment in the design of democratic governance that attempt to address the challenge of a loss of democratic vitality. Heller (2001) refers to participatory governance as a "distinctly democratic version of decentralisation, defined by an increase in the scope and depth of subordinate group participation in authoritative resource allocation". In addition the advance of participatitory governance was parallel and taken place concurrently with the movement toward more decentralized governmental structures. Both decentralization and the emphasis on participation became an integral part of the "third wave" of democratization, as countries around Latin America, Asia, Africa, and Eastern Europe began to hold regular and free elections (Wampler \& McNulty, 2012).

A range of experiences shows that community participation can improve the efficiency of programs (in terms of uses of resources) and effective projects (that achieve their intended outcomes) in the provision and delivery of services, in both the developed and developing worlds. (Fischer, 2012). Moreover, an emphasis on efficiency typically leads to improved monitoring processes and verification of results. Meanwhile Coelho \& Favareto (2011) amplify that participation could contribute to more viable and just policies, and have a positive impact on poverty, inequality and development processes. And participation also can promote access to public policies, and their quality and responsiveness (Coelho \& Favareto, 2011).

The impact of participatory governance initiative to empower women in developing countries remains problematic. In the city of Indore in India induced participatory governance initiative has been successfully empowering women of traditioinally disadvantaged group in community-level water governance (Das, 2014). On the contrary, other cases like in Peru (McNulty, 2015, 2018) similiar initiatives fail to brings a positive change to women of disadvantaged groups. The findings of Gaventa \& Barrett (2012) from their systematic review of participatory governance suggest that producing inclusive society is still the biggest challenge for such initiative. Furthermore, Speer (2012) based on literature review came to a conclusion that the implementation of participatory governance do not always deliver public benefits. Pharased differently, the implementation of participatory governance sometimes failed in delivering better public services, improving accountability and responsiveness of local governments, and ineffective in tackling problems such as elite capture and corruption.

\subsection{Limited Participation in Determining Village Development Priorities}

In the nascent stage of the implementation of the Village Law, SMERU (2017, 2019) and World Bank (2018) suggest that participation in village meetings to determine development priorities is not inclusive. These studies found that in some villages, such meetings are mostly attended by men and village elites, such as government leaders and community figures. Moreover, these studies also revealed that the men who participated were more engaged during this meeting. Therefore, they are significantly influential in the results of such meetings or decision-making processes. On the other hand, Sambodho (2019) indicated that the marginalized groups, including poor families, are completely excluded in this process. Quite contrary to village meeting, SMERU $(2017,2019)$ and World Bank (2018) converge that consultative meeting that mostly held at hamlets were more inclusive in terms of participants, socio-economic backgrounds, and sexes.

World Bank (2018) revealed that in 10 villages under the study situated in various Indonesian regions, the average number of participants in village meetings ranged from around 10 to 70 participants. SMERU (2019b) found that over the course of three years, from 2016-2018, women participants made up for around $30 \%$ on an average in village meetings and about $14 \%$ of them were actively engaged or had a say in the process.

Further, the World Bank (2018) also revealed that village meetings in most villages under their study were normally controlled by village heads, who, in turn, selectively invited meeting attendees. In this regard, villagers who are more likely to be invited are those who have concerns about village affairs and are active in village or community activities and groups that share 
positive opinions of the village government. This includes figures from women's groups that exist in villages, such as PKK, Posyandu, and religious-based women's groups (SMERU, 2017, 2019b).

However, there is a conflicting claim about their engagement in village development planning processes. SMERU (2017) and Syukri (2019) agreed that such participants tend to be passive and silent. This claim is also in line with Blackburn (2004), who suggested that most women's organizations are frail in relation with governments in their efforts to improve women's wellbeing. Nevertheless, her argument is more likely for the representation of women's groups' experiences during the New Order era, which is highly suppressive of civil society organizations.

Moreover, Blackburn (2004) and Beard and Cartmill (2007) also asserted that the New Order was relatively successful in influencing and shaping Indonesian women's citizenship through its gender ideology, which defines how men and women should contribute to national development. The New Order saw women as a significant structural group that needed to be brought in line with its search for harmony and development in the society. It said that women should play their part in ensuring social stability, implementing development plans, and reducing the birth rate (Blackburn, 2004). In this regard, Beard and Cartmill (2007) argued that to understand women's participation in community participatory development planning in Indonesia, one should consider the legacy of New Order. At the same time, the authors also underlined the importance of individual characteristics, such as education and economic status, in influencing women's engagement in civic activities.

On the contrary, World Bank (2018) claimed that they "were less reluctant to talk in public forums and were thus better able to help air the voices of their fellow female villagers." In addition, their capacity to engage in village meetings is relatively comparable with their male counterparts as vocal and active participants in meetings. Unfortunately, World Bank (2018) did not elaborate on these women demographic and socioeconomic characteristics in relation to their participation in village development planning processes.

\subsection{Improving Women's Participation}

Speer (2012) reveals that those cases of successful participatory governance were characterized by first, the presence of highly committed public officials who interested in participatory governance and they need to be able to comply with their promises. In this line, Mansuri \& Rao (2013) underlies the importance of responsive states in ensuring that the participatory processes are exercised in compliance with rules.
Furthermore Mansuri \& Rao (2013) suggests the need of participatory intervention to guarantee that women and other disadvantaged groups are included in the process.

Second, the presence of civil society actors willing to actively engage with citizens and government in participatory processes. Within this thread Fischer (2012) notes that equitable outcomes of participatory governance more commonly occur when the following factors are in place, such as relatively equal the distribution of power, high motivation levels of the participants, and the presence of groups that can facilitate the process. Meanwhile, Gaventa \& Barrett (2012) based on their meta case analysis of four types citizen engagement practices including formal participatory governance space suggests that effective citizens participation alone cannot guarantee to make governments responsive to their voices and demands. However, it should be backed with other forms of engagement outside these participatory spaces. McNulty \& Wampler (2011) and Mansuri \& Rao (2013) unpack another important aspect about the feasibility of participatory governance in delivering positive outcomes. They agree that positive outcomes of participatory governance to the higher extent will not delivered in short and predictable period.

From gender literature Agrawal (2001) noted that improving women's participation in community participatory development depends on women's capacity to deal with rules, norms, and other constraining factors that discourage their meaningful participation. Meanwhile Das (2014) suggests that improving the quality of women's participation can be done by narrowing the gap between women's motivation to participate and their ability to do so. Her key finding concerning women' participation in community-level water governance suggests that the presence of institutional support from government officials and spatial context which make possible for women to interact and know each other help shape and strengthen their solidarity which encourage them to change rules, social norms, and perception that barrier their participation. Das (2014) emphasizes on the organization of women in groups and their solidarity rather than viewing women as individual participant. She argue that women's group participation in participatory decision-making is more effectual in exercising voice and choice than individuals women's participation. This argument is in line with Agrawal (2001) who states that that meaningful participation demands women's involvement not just as individuals but as a collectivity. 


\section{Conclusion}

The introduction of participatory processes concerning village development planning open up the opportunity for village communities to shape village development priorities. Antlov et al. (2016) noted that this change is conducive in improving village decentralization which has been started since 2001. The present paper aims to review body of literature concerning participatory processes in the local level development to ensure that women and other historically marginalized groups have chance to participate meaningfully in these processes.

The reviewed literature informs us that there are seemingly a gap between what scholars believe about participatory processes virtues and limited impact of such initiatives as reported by Speer (2012), Gaventa \& Barrett (2012), and McNulty (2012). Similarly, within this nascent stage of village law implementation participatory spaces in determining village development priorities are still dominated by village elites and men, and village development is heavily focus on infrastructure development. However, the presence and empowered women's organizations or groups which exists in villages might be conducive to help shape village development priorities that are responsive for women.

What we learned from these body of literature is that meaningful participation by women and other historically disadvantaged groups can only be achieved through continuous intervention and facilitation either by dedicated and reform-minded public officials and other critical actors. Furthermore, as Agrawal (2011) and Das (2014) stated women should involve in participatory village development planning as a collective, rather than as individuals.

\section{References}

Agrawal, B. (2001). Participatory Exclusions, Community Forestry, and Gender: An Analysis for South Asia and a Conceptual Framework. World Development, 29 (10) 1623 - 1648.

Antlöv, H., Wetterberg, A., \& Dharmawan, L. (2016). Village governance, community life, and the 2014 Village Law in Indonesia. Bulletin of Indonesian Economic Studies, 52(2) 161-183.

Antlöv, H. (2003). Village government and rural development In Indonesia: The new democratic framework. Bulletin of Indonesian Economic Studies, 39(2) 193-214.

Antlov, H., \& Eko, S. (2012). Village and sub-district functions in decentralized Indonesia. Paper prepared for Decentralization Support Facility (DSF) closing workshop in Jakarta, 12-13 March 2012.
Asian Development Bank (ADB). (2016). Toward Mainstreaming And Sustaining Community-Driven Development In Indonesia: Understanding Local Initiatives And The Transition From The National Rural Community Empowerment Program To The Village Law. ADB.

Beard, V. A., \& Cartmill, R. S. (2007). Gender, collective action and participatory development in Indonesia. International Development Planning Review (IDPR), 29(2) 185-213.

Blackburn, S. (2004). Women and the State in Modern Indonesia. Cambridge University Press.

Cleaver, F. (1999). Paradox of Participation: Questioning participatory approaches to Development, Journal of International Development, 11 (1) 597 - 612.

Coelho, V. S. P., \& Favareto, A. (2011). Participatory Governance and Development: In Search of a Causal Nexus. Geography Compass, 5 (9) 641-654.

Cornwall, A. (2003). Whose Voices? Whose Choices? Reflections on Gender and Participatory Development. World Development, 31 (8) 13251342.

Das, P. (2014). Women's Participation in CommunityLevel Water Governance in Urban India: The Gap Between Motivation and Ability. World Development 64(2) 206-218.

Fischer, F. (2012). Participatory Governance: From Theory To Practice, in Levi-Faur, David (ed). The Oxford Handbook of Governance. Oxford University Press.

Fung, A., \& Wright, E.O. (2001). Deepening Democracy: Innovations in Empowered Participatory Governance. Politics \& Society 29 (1) 5 - 41.

Gaventa, J., \& Barrett, G. (2012). Mapping the Outcomes of Citizen Engagement. World Development 40 (12) 2399-2410.

Gibson, C., \& Woolcock, M. (2008). Empowerment, Deliberative Development, and Local-Level Politics in Indonesia: Participatory Projects as a Source of Countervailing Power. St Comp Int Dev 43(2) 151 180.

Heller, P. (2001). Moving the State: The Politics of Democratic Decentralization in Kerala, South Africa, and Porto Alegre. Politics \& Society, 29 (131) 131 163.

Hicks, J. (2011). Bringing women into local governance: a review of enabling mechanisms in South Africa. Community Development Journal 46 (3) $351-354$.

Mansuri, G., \& Rao, V. (2013). Localizing development: does participation work? World Bank.

Masanyiwa, Z.S., Niehof, A., \& Termeer, C.J.A.M. (2014). Gender perspectives on decentralisation and 
service users' participation in rural Tanzania. The Journal of Modern African Studies ,52 (1) 95 - 122.

McNulty, S. (2018) Embedded exclusions: exploring gender equality in Peru's participatory democratic framework, Global Discourse, 8 (3) 532 -549.

McNulty, S. (2015) Barriers to Participation: Exploring Gender in Peru's Participatory Budget Process, The Journal of Development Studies, 51 (11) 1429 - 1443.

Ministry of Home Affairs (MOHA) Regulation 114/201. (2014). General Guideline of Village Development. Jakarta: MOHA.

National Team for the Acceleration of Poverty Reduction (TNP2K). (2015). Integrating Community-Driven Development Principles Into Policy: From Pnpm Mandiri To The Village Law. Secretariat of the Vice President of the Republic of Indonesia.

Sambodho, J. P. (2019). Choosing the playing field: Non-participation in the village level participatory deliberative forums. MASYARAKAT Jurnal Sosiologi 24 (2) 143-165.

SMERU Research Institute. (2017). Study on the Implementation of Law No. 6/2014 on Villages Baseline Report. SMERU Research Institute - Local Solutions to Poverty.

SMERU Research Institute. (2019a). Tracking Village Fund Spending and Benefits: Case Study Report (in Indonesian), SMERU Research Institute - Local Solutions to Poverty.

SMERU Research Institute. (2019b). Study on the Implementation of Law No. 6/2014 on Villages: Endline Report (in Indonesian). SMERU Research Institute - Local Solutions to Poverty.

Speer, J. (2012). Participatory Governance Reform: A Good Strategy for Increasing Government Responsiveness and Improving Public Services? World Development, 40(12) 2379-2398.

Sutiyo, S., \& Maharjan, K. L (2013) Community Participation in Decentralized Rural Development: A Case Study of Three Villages in Purbalingga District, Indonesia. Journal of International Development and Cooperation, 18 (3) 99 -110.

Syukri, M. (2019). Gender Equality in Indonesian New Developmental State: The Case of the New Participatory Village Governance. The SMERU Research Institute.

Usui, N., \& Alisjahbana, A. S. (2005). Local development planning and budgeting in decentralized Indonesia: Missing links in the bottom-up approach. Kansai University Review of Economics 7: 71-97.

Widianingsih, I., \& Morrell, E. (2007). Participatory planning in Indonesia. Policy Studies 28(1): 1-15.

Wampler, B. \& McNulty, S. (2011). Does participatory governance matter? Exploring the nature and impact of participatory reforms. Washington, DC: Woodrow Wilson International Center for Scholars.

World Bank. (2018). Participation, Transparency and Accountability in Village Law Implementation (Baseline Findings from the Sentinel Villages Study October 2015-February 2016. Jakarta: The World Bank - Local Solutions to Poverty. 